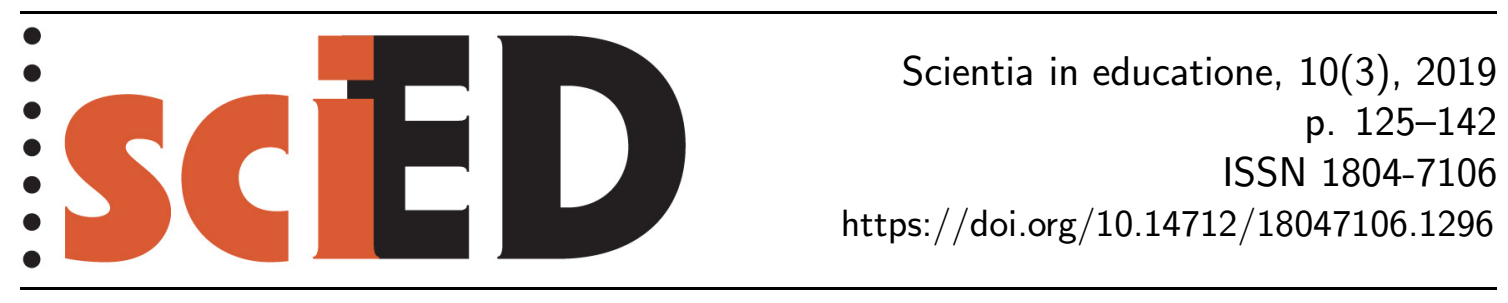

\title{
A Comparative Study of Biology Curricula in England, Scotland and the Czech Republic
}

\author{
Jakub Holec
}

\begin{abstract}
In recent years, both in the Czech Republic and abroad, there has been a debate about the renaissance of educational content and its intended form expressed in national curricula. From the curriculum analyses point of view, it is highly interesting to compare similar curricula created in different contexts, on the one hand, and different curricula created in similar contexts on the other hand. On the basis of the context-curriculum analysis, the curricula of England, Scotland and the Czech Republic were selected. The paper seeks to explore biology education in three National Curriculum Frameworks in the field of primary and lower secondary education. The comparative analysis is a tool for a deeper understanding the intended learning objectives as stated in the curricula. It provides an opportunity to compare different types of curricula and analyse biology content organization and the cognitive demands of the respective disciplinary knowledge, at least judging from the curriculum documents. The paper contributes to comparative curriculum research and provides the knowledge needed for the future process of curriculum review in the Czech Republic. I conclude that, while all these curricula emphasize learning outcomes and experiences, there are distinct differences between them in a stronger emphasis on the disciplinary knowledge or developing transversal competencies. It is reflected in both the learning outcomes formulation and the level of their specificity. This paper offers a contribution to the debate about the way in which particular disciplinary content is organized and taught from the perspective of a specific curriculum policy.
\end{abstract}

Key words: curriculum, curriculum policy, biology, learning objectives.

\section{Srovnávací studie kurikula biologie $\mathrm{v}$ pojetí Anglie, Skotska a České republiky}

\begin{abstract}
Abstrakt
V posledních letech se $\mathrm{v}$ zahraničí i v českém prostředí mluví o obnovení tematiky obsahu vzdělávání, jehož zamýšlenou podobu vyjadřují kurikulární dokumenty. Z hlediska komparace kurikul je zajímavé zkoumat obdobně pojatá kurikula, která vznikla v odlišných socio-kulturních kontextech a naopak odlišně pojatá kurikula, která vznikla v obdobných kontextech. Na základě analýzy „kontext-kurikulum“ byla vybrána kurikula Anglie, Skotska a České republiky. Příspěvek se zaměřuje na komparaci pojetí biologického vzdělávání ve třech národních kurikulárních rámcích pro oblast primárního a nižšího sekundárního
\end{abstract}


vzdělávání. Srovnávací analýza je nástrojem k hlubšímu porozumění tomu, jak se ve srovnávaných kurikulech přistupuje $\mathrm{k}$ formulování zamýšlených cílů vzdělávání. To nabízí př́ležitost ke komparaci různých typů kurikul a analýzám obsahu oborových znalostí biologie a jejich uspořádání $\mathrm{v}$ kurikulu. Příspěvek obohacuje současný diskurz srovnávací pedagogiky a přináší znalostí, ze kterých mohou vycházet budoucí revize kurikula biologie v Ceské republice. Docházím k závěru, že všechna analyzovaná kurikula akcentující vzdělávací výstupy a zkušenosti se v zásadních rysech liší ve formulaci vzdělávacích výstupů i úrovni konkrétnosti jejich rozpracování. Text nabízí prř́ležitost k debatám týkající se způsobu, kterým se z pohledu vybraných vzdělávacích politik přistupuje k formulování a strukturaci předmětového obsahu v kurikulu.

Klíčová slova: kurikulum, vzdělávací politika, biologie, vzdělávací cíle.

In the past two decades, a consensus across the European Union countries has emerged that the science curriculum should be focused mainly on developing key competencies. The tendency stems from adopting the Lisbon Agenda, which underlined the crucial importance of the acquisition of competencies for the wellbeing of citizens, social cohesion, economic development and competitiveness (Council of the European Union, 2000). In consequence of the ongoing social and economic changes brought about by progress in science and technology, people are strongly concerned about how the school curriculum responds and prepares learners to meet the needs of, what Drucker (2004) calls the "knowledge society". These economic and social changes require young people to gain a wide range of knowledge, skills, attitudes, and values in order to prosper in the current ever-changing societies. The European Union has defined eight key competencies to be acquired during compulsory schooling, amongst which is competence in science (Council of the European Union, 2018).

However, whilst there is a general agreement that science education is highly important for all educational systems, there has been little research about its structure and contents (Osborne \& Dillon, 2008). As a part of studies on curricula, international comparisons become increasingly helpful for curriculum planning. Even countries achieving excellent educational results (e.g. Finland, Estonia, Canada) are systematically studying the results of international comparisons and are constantly trying to find an optimal solution for improving their own curriculum (Schmidt et al., 2001; Oates, 2011). International comparisons provide a tool for recognizing factors that have a significant effect on educational processes and results. Indeed, the statutory national curriculum has a crucial impact on the way in which teachers plan their school-based curriculum (Schmidt \& Prawat, 2006).

Nowadays, the national curriculum review takes place in the Czech Republic. The curriculum revision constitutes a cyclic process that starts with an analysis of the current and desired situation, including context analysis, needs analysis and an exploration of the existing knowledge base (van den Akker, 2004). The paper contributes to the analytical phase of curriculum planning as comparative research about the structure and content of curriculum frameworks that can serve as an inspiration for the national curriculum design.

This study is related to the development of macro-level educational policies and curricular documents, not the actual practice in schools and classrooms. The text is focused on analyzing national curricula for science/biology during compulsory 
education in England, Scotland and the Czech Republic. The aim of the comparative analyses is to answer the following research questions:

1. How the compared curricula adopt global culture of education and policy borrowing?

2. How the compared curricula differ in the biology content organisation and in cognitive difficulty and progression of the statements of learning outcomes and objectives?

National curriculum documents analysed in the study:

- National Curriculum (NC): England (Department for Education, 2013, 2014)

- Curriculum for Excellence (CfE): Scotland (Scottish Executive, 2004)

- Framework Educational Programme (FEP): the Czech Republic (VÚP, 2007)

\section{TheOreticAl FramewORK}

The actual discussion refers to two theoretical perspectives, which have a significant influence on current comparative educational research - the theory of new institutionalism and the theory of policy borrowing. New institutionalism (Meyer \& Rowan, 2006; Meyer, 2010; Ramirez \& Meyer, 2002; Wiseman, Astiz \& Baker, 2014) postulates that the spread of the global culture of education dominates reform processes in different parts of the world. Some nations, however, imitate the global models quite superficially. The concept of "loose coupling" explains changes and divergence from an original model, which may happen in a particular country during the adoption and implementation of the reform process. Understanding whether and why there have been identifiable global changes resulting in a putative international core curriculum may reveal which strategies and topics countries have recognized as supporting future skills and knowledge (Stecey et al., 2018).

Linked to the rising influence of international large-scale assessments is "policy borrowing", where countries adopt education reforms and policies that have been successfully implemented in other countries, typically high-performing jurisdictions. The theory of policy borrowing posits, in some cases, that educational reforms are borrowed on the principle of "solutions first". In education, the study of policy borrowing has helped to substantiate and legitimise the field of comparative education. However, learning from comparison does not necessarily mean that policies and practices should be transferred from one context to another. International comparison is not a tool for analysing education out of context and against using comparisons to transplant educational reforms from one country to another. The policy borrowing tends to be a one-way process: the Western/ English speaking nations are typical "lending" countries of policy origin, while post-socialistic and post-colonial countries are borrowing policies. The borrowing process in Central/Eastern European countries may face lack of necessary capacity and resources to emulate Western models (Pritchett, Woolcock \& Andrews, 2010; Dvořák \& Holec, submitted). The process of policy borrowing always includes policy translation, i.e., local adaptation, modification or re-framing (Steiner-Khamsi, 2014).

These two theoretical perspectives provide enable us to study the process of curriculum development in different local contexts. They offer a deeper understanding of how the compared curricula differ in the aims and objectives of particular learning content. The English National Curriculum, the Scottish Curriculum for Excellence (CfE) and the Czech Framework Educational Programme were selected 
on the basis of context-curriculum analysis. For the comparative analysis, the similar curricula developed in different sociocultural contexts (CfE, FEP) and different curricula developed in similar local contexts were selected. CfE and PEP are based on very similar principles promoting general key competencies, cross-curricular topics and the key role of teachers as agents of change (Priestley \& Humes, 2010; Holec \& Dvořák, 2017). Both of them represent a shift from a centrally prescribed curriculum oriented on knowledge transmission to a more progressive curriculum based on principles of constructivism (Walterova, 1994; Hutchinson \& Hayward, 2005). Typically, this type of curriculum is predicated around a view of what an autonomous adult should be and a learning process (often dialogical, inquiry-based and experiential) that may serve as the route to achieving these learning objectives.

English NC represents a different model of curriculum. It is acknowledged as a mainly knowledge-oriented curriculum embodying rigor and high standards in the key disciplines and focus on the aims of comprehensive knowledge or skill in a particular subject or activity (Priestley \& Humes, 2010; DfE, 2013). In NC, key competencies are not mentioned explicitly. Comprehensive skills and competencies are part of particular learning content (see Tab. 1).

Tab. 1: A comparison of general key competencies in three curriculum frameworks for primary and lower secondary education

\begin{tabular}{|c|c|c|}
\hline $\begin{array}{l}\text { National Curriculum } \\
\text { (2013, 2014) England }\end{array}$ & $\begin{array}{l}\text { Curriculum for } \\
\text { Excellence (2004) } \\
\text { Scotland }\end{array}$ & $\begin{array}{l}\text { Framework Education } \\
\text { Programme (2007) Czech } \\
\text { Republic }\end{array}$ \\
\hline \multirow{5}{*}{$\begin{array}{l}\text { Competencies are not } \\
\text { mentioned explicitly. } \\
\text { (key skills as part of } \\
\text { disciplinary learning } \\
\text { content). }\end{array}$} & Successful learners & Learning Competency \\
\hline & Confident individuals & $\begin{array}{l}\text { Problem-Solving Competency } \\
\text { Communication Competency }\end{array}$ \\
\hline & \multirow{2}{*}{ Responsible citizens } & Social and Personal Competency \\
\hline & & Civic Competency \\
\hline & Effective contributors & Professional Competency \\
\hline
\end{tabular}

The curriculum consists of a set of content items, most common knowledge, skills and attitudes that should be gain by all pupils in all schools. These items are organized into particular disciplines and further into thematic areas. Disciplinary curriculum position knowledge is organised either horizontally or vertically. Horizontal organisation means the particular learning content splits into a list of thematic areas. On the other hand, the vertical organisation shows the sequencing of particular learning content in different stages of education (Goodlad \& Su, 1992).

All the compared curricula use the educational aims set for particular disciplines and educational levels (stages) in terms of learning outcomes. Firstly, learning outcomes in biology can be organised into thematic areas consistent with biology organism classification. This systematic approach uses the Linnaeus system for classifying organisms into plants, animals, minerals, etc. In my opinion, the approach represents a traditional academic view on structuring the biology curriculum. On the other hand, there is an attempt to connect science education to everyday life experience. This approach leads to more practically oriented concepts, such as "Towards a sustainable future" and "What is life?" Science education based on developing these science concepts is focused on the centrality of pupils in the learning process (Škoda \& Doulík, 2009). Nowadays, science curricula are structured into key scientific concepts emphasizing the nature of science and its relevance for pupils. It is highly interesting to compare a mainly competence-based curriculum and a mainly subject-based curriculum. 
The curricula for the content analyses were not selected in relation to achieved curriculum and educational results. In my study, I am interested in formal curriculum documents that play a limited role in teaching and learning. Despite this fact, I provide a short insight into science education results according to PISA 2015 international survey of scientific literacy for the selected countries. The mean score of English pupils in scientific literacy performance is higher in comparison to Scottish and Czech pupils. Pupils in England scored 512 points - above the OECD average, whilst pupils in Scotland scored 497 points and Czech pupils scored 493 points both around the OECD average (Blažek \& Př́hodová, 2016) Mean performance in science has not changed since 2006 for students in England, while it has declined both in Scotland and the Czech Republic remarkably (OECD, 2016).

\section{METHODOLOGY}

In conducting the analysis, I employed a case study approach, using document content and comparative analysis to examine curriculum policy texts. The purpose of looking to national curriculum frameworks of England, Scotland and the Czech Republic was not specifically to compare the context of these three curricula, but rather to enable a deeper understanding of the way in which they position a biology curriculum. The document analysis approach dealt with actual written texts (Bowen, 2009). The study is aiming at finding out how the biology curriculum of each country differs in a specific disciplinary structure and the nature of knowledge presented by particular learning outcomes. For the text analysis, it is used a qualitative research design.

Firstly, a list of the thematic areas covering biology education in all curricula was selected. Secondly, categories for the analysis were defined beforehand. For this purpose, it is employed a category system defined in the PISA 2015 Assessment and Analytical Framework for Science (OECD, 2016) and the TIMSS 2015 Science Framework (Mullis \& Martin, 2014). The frameworks provide us with life science concepts covering both PISA and TIMSS international assessments in the field of science and scientific literacy. From the PISA and TIMSS frameworks, two life science (biology) topics were analysed in each curriculum: food chains, cell and its organisation. For analysing the corresponding learning content of each curriculum, these two PISA and TIMSS assessment topics were used. For this purpose, the analysis is focused on how the particular statement of learning outcomes differs in cognitive demands. For this purpose Bloom's taxonomy of the cognitive domain (Anderson \& Krathwohl, 2001) was used. Apart from this analysis, the specific learning outcomes progression in each curriculum was examined with the aim of uncovering how the learning objectives are revisited at a higher-order cognitive level (Bruner, 1960).

\section{The Curriculum Content Analyses}

Before the comparison, I first provide a brief overview of the key features and undertake a content analysis of each curriculum. The content analysis is focused on the science curriculum and the position of biology knowledge and scientific skills in the curriculum documents. The text studies how the science content is organised within each curriculum with a focus on biology instruction. 
Tab. 2: An example of "working scientifically" topics in the National curriculum (Department of Education 2013, 2014)

\begin{tabular}{|c|c|c|c|c|}
\hline Key stage & $\begin{array}{l}\text { KS1 } \\
\text { (age 5-7) }\end{array}$ & $\begin{array}{l}\text { KS2 } \\
(\text { age } 7-11)\end{array}$ & $\begin{array}{l}\text { KS3 } \\
\text { (age 11-14) }\end{array}$ & $\begin{array}{l}\text { KS4 } \\
\text { (age 14-16) }\end{array}$ \\
\hline $\begin{array}{l}\text { Learning } \\
\text { areas }\end{array}$ & Science & Science & Biology & Biology \\
\hline $\begin{array}{l}\text { Scientific } \\
\text { skills }\end{array}$ & \multicolumn{2}{|c|}{$\begin{array}{l}\text { Working scientifically (Practical } \\
\text { scientific methods, processes and } \\
\text { skills through the teaching) }\end{array}$} & $\begin{array}{l}\text { Working } \\
\text { scientifically } \\
\text { (Scientific } \\
\text { attitudes, } \\
\text { Experimental } \\
\text { skills and } \\
\text { investigations, } \\
\text { Analysis and } \\
\text { evaluation, } \\
\text { Measurement) }\end{array}$ & $\begin{array}{l}\text { Working } \\
\text { scientifically } \\
\text { (The development } \\
\text { of scientific } \\
\text { thinking, } \\
\text { Experimental skills } \\
\text { and strategies, } \\
\text { Analysis and } \\
\text { evaluation, } \\
\text { Vocabulary, units, } \\
\text { symbols and } \\
\text { nomenclature) }\end{array}$ \\
\hline \multirow[t]{10}{*}{$\begin{array}{l}\text { Thematic } \\
\text { areas }\end{array}$} & Plants (Y1, Y2) & Plants (Y3) & $\begin{array}{l}\text { Cells and } \\
\text { organisation }\end{array}$ & Cell biology \\
\hline & $\begin{array}{l}\text { Animals, } \\
\text { including humans } \\
(\mathrm{Y} 1, \mathrm{Y} 2)\end{array}$ & $\begin{array}{l}\text { Animals, } \\
\text { including humans } \\
(\mathrm{Y} 3, \mathrm{Y} 4, \mathrm{Y} 5, \mathrm{Y} 6)\end{array}$ & $\begin{array}{l}\text { The skeletal and } \\
\text { muscular } \\
\text { systems }\end{array}$ & \\
\hline & $\begin{array}{l}\text { Seasonal changes } \\
\text { (Y1) }\end{array}$ & & $\begin{array}{l}\text { Nutrition and } \\
\text { digestion }\end{array}$ & Transport systems \\
\hline & $\begin{array}{l}\text { Living things and } \\
\text { their habitats } \\
\text { (Y2) }\end{array}$ & $\begin{array}{l}\text { Living things and } \\
\text { their habitats } \\
(\mathrm{Y} 4, \mathrm{Y} 5, \mathrm{Y} 6)\end{array}$ & $\begin{array}{l}\text { Gas exchange } \\
\text { systems }\end{array}$ & $\begin{array}{l}\text { Coordination and } \\
\text { control }\end{array}$ \\
\hline & & $\begin{array}{l}\text { Earth and space } \\
\text { (Y5) }\end{array}$ & Reproduction & \\
\hline & & $\begin{array}{l}\text { Evolution and } \\
\text { inheritance (Y6) }\end{array}$ & Health & $\begin{array}{l}\text { Health, disease and } \\
\text { the development of } \\
\text { medicines }\end{array}$ \\
\hline & & & Photosynthesis & Photosynthesis \\
\hline & & & $\begin{array}{l}\text { Cellular } \\
\text { respiration }\end{array}$ & \\
\hline & & & $\begin{array}{l}\text { Relationships in } \\
\text { an ecosystem }\end{array}$ & Ecosystems \\
\hline & & & $\begin{array}{l}\text { Genetics and } \\
\text { evolution }\end{array}$ & $\begin{array}{l}\text { Evolution, } \\
\text { inheritance and } \\
\text { variation }\end{array}$ \\
\hline
\end{tabular}

\section{The National Curriculum Case}

In England, primary and secondary education is compulsory between the age of 5 and 16. In 1988, the Education Reform Act introduced in England the compulsory National Curriculum. The majority of the current national curriculum was introduced in September 2014. The curriculum sets out the programmes of study and attainment targets for all subjects at all four key stages. In addition to identifying the main directions of educational processes, including science education, the National Curriculum contains a detailed specification of skills, which students 
should obtain at specific educational stages. The compulsory state education system in England consists of three stages/levels - Key Stage 1 (KS1), Key Stage 2 (KS2), Key Stage 3 (KS3), Key Stage 4 (KS4). Biology content is a part of Science education during KS1 and KS2, while there is a separate Biology subject from KS3 and KS4 (Department for Education, 2013; Department for Education, 2014).

The national curriculum for science aims to ensure that all pupils develop scientific knowledge and conceptual understanding through the specific scientific disciplines. The curriculum focuses on content knowledge of traditional science disciplines. The learning objectives emphasize the position of traditional subject disciplines with the aim of developing a secure understanding and skills within the disciplinary key concepts. By the end of each key stage, pupils are expected to know, apply and understand the knowledge, skills and processes specified in the relevant programme of study (Department for Education, 2014).

The structure of the curriculum for biology represents a combination of traditional content classification into systematic categories (plants, animals including human, rocks, etc.), along with a classification using crucial biology concepts (cells, genetics and evolution, photosynthesis, etc.). Except for the disciplinary content, the curriculum also emphasizes scientific skills that should be developed across the science disciplines. Tab. 2 shows a list of biology topics in the curriculum through four key stages.

The disciplinary objectives include content knowledge together with procedural knowledge and skills. The learning outcomes set the specific knowledge and skills that pupils should gain further learning progress in the next programme of study. While the primary education highlights basic cognitive educational aims, the lower secondary education underlines the position of knowledge application in order to solve scientific problems (see Tab. 3).

Tab. 3: A vertical structure of learning content representing the National Curriculum (England). The concept of "food chains" was used for the illustration of topic progression (Department of Education 2013, 2014)

\begin{tabular}{lll}
\hline Pupils should be taught about: & \\
\hline $\begin{array}{l}\text { Key Stage 1 } \\
\text { (age 5-7) }\end{array}$ & $\begin{array}{l}\text { Key Stage 2 } \\
\text { (age 7-11) }\end{array}$ & $\begin{array}{l}\text { Key Stage 3 } \\
\text { (age 11-14) }\end{array}$ \\
\hline $\begin{array}{l}\text { Describe how animals } \\
\text { obtain their food from } \\
\text { plants and other animals, } \\
\begin{array}{l}\text { using the idea of a simple } \\
\text { food chain, and identify and } \\
\text { name different sources of }\end{array}\end{array}$ & $\begin{array}{l}\text { a variety of food chains, } \\
\text { identifying producers, } \\
\text { predators and prey. }\end{array}$ & $\begin{array}{l}\text { The interdependence of } \\
\text { organisms in an ecosystem, } \\
\text { including food webs and } \\
\text { insect pollinated crops. }\end{array}$ \\
\hline
\end{tabular}

Working scientifically specifies the understanding of the nature, processes and methods of science for each year group. It should not be taught as a separate strand. These types of scientific enquiry should include: observing over time; pattern seeking; identifying, classifying and grouping; comparative testing; and researching using secondary sources. Pupils should seek answers to questions through collecting, analysing and presenting data. Table 4 shows learning objectives related to scientific skills and its subcategories. Apart from "working scientifically", the table also contains learning outcomes for specific disciplinary content: "cells". 
Tab. 4: Learning objectives for developing scientific skills and procedural knowledge by 11-14 years pupils (Department of Education 2013, 2014)

\begin{tabular}{|c|c|}
\hline $\begin{array}{l}\text { Working } \\
\text { scientifically }\end{array}$ & $\begin{array}{l}\text { Through the content across all three disciplines, pupils should be taught } \\
\text { to: }\end{array}$ \\
\hline $\begin{array}{l}\text { Scientific } \\
\text { attitudes }\end{array}$ & $\begin{array}{l}\text { - pay attention to objectivity and concern for accuracy, precision, } \\
\text { repeatability and reproducibility } \\
\text { - understand that scientific methods and theories develop as earlier } \\
\text { explanations are modified to take account of new evidence and ideas, } \\
\text { together with the importance of publishing results and peer review } \\
\text { - evaluate risks }\end{array}$ \\
\hline $\begin{array}{l}\text { Experimental } \\
\text { skills and } \\
\text { investigations }\end{array}$ & $\begin{array}{l}\text { - ask questions and develop a line of enquiry based on observations of } \\
\text { the real world, alongside prior knowledge and experience } \\
\text { - make predictions using scientific knowledge and understanding } \\
\text { - select, plan and carry out the most appropriate types of scientific } \\
\text { enquiries to test predictions, including identifying independent, } \\
\text { dependent and control variables, where appropriate } \\
\text { - use appropriate techniques, apparatus, and materials during } \\
\text { fieldwork and laboratory work, paying attention to health and safety } \\
\text { - make and record observations and measurements using a range of } \\
\text { methods for different investigations; and evaluate the reliability of } \\
\text { methods and suggest possible improvements } \\
\text { - apply sampling techniques. }\end{array}$ \\
\hline $\begin{array}{l}\text { Analysis and } \\
\text { evaluation }\end{array}$ & $\begin{array}{l}\text { - apply mathematical concepts and calculate results } \\
\text { - present observations and data using appropriate methods, including } \\
\text { tables and graphs } \\
\text { - interpret observations and data, including identifying patterns and } \\
\text { using observations, measurements and data to draw conclusions } \\
\text { - present reasoned explanations, including explaining data in relation } \\
\text { to predictions and hypotheses } \\
\text { - evaluate data, showing awareness of potential sources of random and } \\
\text { - identematic error }\end{array}$ \\
\hline Measurement & $\begin{array}{l}\text { - understand and use SI units and IUPAC (International Union of } \\
\text { Pure and Applied Chemistry) chemical nomenclature } \\
\text { - use and derive simple equations and carry out appropriate } \\
\text { calculations } \\
\text { - undertake basic data analysis including simple statistical techniques. }\end{array}$ \\
\hline $\begin{array}{l}\text { Disciplinary } \\
\text { content - } \\
\text { Biology }\end{array}$ & Pupils should be taught about: \\
\hline $\begin{array}{l}\text { Cells and } \\
\text { organisation }\end{array}$ & $\begin{array}{l}\text { - cells as the fundamental unit of living organisms, including how to } \\
\text { observe, interpret and record cell structure using a light microscope } \\
\text { - the functions of the cell wall, cell membrane, cytoplasm, nucleus, } \\
\text { vacuole, mitochondria and chloroplasts } \\
\text { - the similarities and differences between plant and animal cells } \\
\text { - the role of diffusion in the movement of materials in and between } \\
\text { cells } \\
\text { - the structural adaptations of some unicellular organisms } \\
\text { - the hierarchical organisation of multicellular organisms: from cells to } \\
\text { tissues to organs to systems to organisms. }\end{array}$ \\
\hline
\end{tabular}




\section{The Curriculum for Excellence Case}

Curriculum for Excellence is the Scottish national curriculum for learners from the ages $3-15$. The Framework containing aims and principles of the ongoing curriculum reform was published in 2004. The learning outcomes and experiences for specific learning areas including Science were released in 2009 (Scottish Executive, 2007; Holec \& Dvořák, 2017). The curriculum is a basis for school-based curriculum development (Priestley \& Minty, 2012). During all stages of Scottish compulsory education, the biology curriculum is a part of the Science learning area.

The purpose of the curriculum is to help children and young people to become successful learners, confident individuals, responsible citizens and effective contributors (the four capacities). The framework, therefore, puts the learner at the centre of the curriculum. The curriculum areas are the organisers for setting out the experiences and outcomes. In drawing up the experiences and outcomes, learning in each curriculum area emphasizes the contributions it can make to developing the four capacities. Priestley (2010) argues that the shift to learning outcomes represents a move from subject-specific to generic curriculum criteria. The experiences and outcomes have been structured using the following categories: expressive arts; health and wellbeing; languages; mathematics; religious and moral education; science; social studies; and technologies (Scottish Government, 2008). The experiences and outcomes under each learning area are written at four levels for compulsory education. The science key concepts have been structured using five categories: Planet Earth; Forces, electricity and waves; Biological systems; Materials; and Topical science. The thematic categories remains the same for all educational levels. The science curriculum specifies that scientific skills should be developed by the pupils and disciplinary content is expressed as the experiences and outcomes (see Tab. 5).

Tab. 5: List of key science topics in Curriculum for Excellence focusing on scientific skills and biology learning content (Scottish Executive, 2004)

\begin{tabular}{lllll}
\hline Level & $\begin{array}{l}\text { Early } \\
\text { age 3-5) }\end{array}$ & $\begin{array}{l}\text { First } \\
(\text { age 5-8) }\end{array}$ & $\begin{array}{l}\text { Second } \\
\text { age 8-11) }\end{array}$ & $\begin{array}{l}\text { Third, Fourth } \\
\text { (age 11-14) }\end{array}$ \\
\hline Learning area & Science & & & \\
\hline Scientific skills & $\begin{array}{l}\text { Inquiry and investigative skills } \\
\text { Scientific analytical thinking skills }\end{array}$ & \\
\hline \multirow{2}{*}{ Thematic areas } & Biodiversity and interdependence & \\
\cline { 2 - 4 } & Body systems and cells & & \\
\cline { 2 - 4 } & Inheritance & & \\
\hline
\end{tabular}

CfE formulates learning expectation outcomes in terms of experiences, as well as broad significant outcomes, all of that are designed to reflect the four capacities (Scottish Executive, 2006b). These learning statements put emphasis on practical knowledge and its application. Experiences and outcomes are designed from the learner's point of view, using terms like 'I have...' for experiences and 'I can...' for outcomes' (Scottish Executive, 2006a). The use of the first person in these statements is intended to give centre-stage to the learner and emphasize the importance of personal engagement (Pristley \& Humes, 2010). Biesta (2009) refers to this trend as the "learnification" of education. According to Biesta, this tendency reflects an unproblematised acceptance that learning is good and a failure to address educational questions, such as 'what are we learning?' and 'why are we learning it?'. 
Tab. 6: A vertical structure of learning content represented in the Curriculum for Excellence (Scotland). The concept of "food chains" was used for the illustration of the topic progression (Scottish Executive, 2004)

\begin{tabular}{lll}
\hline $\begin{array}{l}\text { P2-4 } \\
\text { (First level), age 5-8 }\end{array}$ & $\begin{array}{l}\text { P5-7 } \\
\text { (Second level), age 8-11 }\end{array}$ & $\begin{array}{l}\text { S1-S3 } \\
\text { (Third and Fourth level), } \\
\text { age 11-14 }\end{array}$ \\
\hline $\begin{array}{l}\text { I can explore examples } \\
\text { of food chains and } \\
\text { show an appreciation } \\
\text { of how animals and } \\
\text { plants depend on each } \\
\text { other for food. }\end{array}$ & $\begin{array}{l}\text { I can use my knowledge of the } \\
\text { interactions and energy flow } \\
\text { between plants and animals in } \\
\text { ecosystems, food chains and webs. }\end{array}$ & $\begin{array}{l}\text { I have contributed to the design or } \\
\text { conservation of a wildlife area. }\end{array}$ \\
\hline
\end{tabular}

Tab. 7: Learning objectives for developing scientific knowledge and procedural knowledge by 11-14 years pupils (Scottish Executive, 2004)

\begin{tabular}{|c|c|}
\hline \multicolumn{2}{|l|}{$\overline{\text { Scientific skills }}$} \\
\hline $\begin{array}{l}\text { Inquiry and } \\
\text { investigative } \\
\text { skills }\end{array}$ & $\begin{array}{l}\text { Through experimenting and carrying out practical scientific } \\
\text { investigations and other research to solve problems and challenges, } \\
\text { children and young people: } \\
\text { - ask questions or hypothesise } \\
\text { - plan and design procedures and experiments } \\
\text { - select appropriate samples, equipment and other resources } \\
\text { - carry out experiments } \\
\text { - use practical analytical techniques } \\
\text { - observe, collect, measure and record evidence, taking account of safety } \\
\text { - pnd controlling risk and hazards } \\
\text { - revient, analyse and interpret data to draw conclusions } \\
\text { - present and report on findings }\end{array}$ \\
\hline $\begin{array}{l}\text { Scientific } \\
\text { analytical } \\
\text { thinking skills }\end{array}$ & $\begin{array}{l}\text { Children and young people develop a range of analytical thinking skills } \\
\text { in order to make sense of scientific evidence and concepts. This } \\
\text { involves them: } \\
\text { - being open to new ideas and linking and applying learning } \\
\text { - thinking creatively and critically } \\
\text { - developing skills of reasoning to provide explanations and evaluations } \\
\text { supported by evidence or justifications } \\
\text { - making predictions, generalisations and deductions } \\
\text { - drawing conclusions based on reliable scientific evidence }\end{array}$ \\
\hline \multicolumn{2}{|c|}{ Disciplinary content - Biology } \\
\hline $\begin{array}{l}\text { Body systems } \\
\text { and cells }\end{array}$ & $\begin{array}{l}\text { - I can explain how biological actions which take place in response to } \\
\text { external and internal changes work to maintain stable body } \\
\text { conditions. } \\
\text { - Through investigation, I can explain how changes in learned } \\
\text { behaviour due to internal and external stimuli are of benefit to the } \\
\text { survival of species. } \\
\text { - By researching cell division, I can explain its role in growth and repair } \\
\text { and can discuss how some cells can be used therapeutically. } \\
\text { - I have taken part in practical activities its impact on the } \\
\text { curriculumvolve the use of enzymes and microorganisms to develop } \\
\text { my understanding of their properties and their use in industries. } \\
\text { I can debate the moral and ethical issues associated with some } \\
\text { controversial biological procedures. }\end{array}$ \\
\hline
\end{tabular}




\section{The Framework Educational Programme Case}

Compulsory education in the Czech Republic covers students aged 6 to 15. The basis for teaching in the Czech education system is the Framework Education Programme for Elementary Education. The Framework was introduced in 2004. Based on the Framework, schools prepared their own School-Based Curriculum Document from 2005 (Tupý, 2014). In primary education (Grade 1-Grade 5), biology is integrated in the subject "Man and his World" (thematic area "Diversity of Nature"). From 6th to 9th grade, biology is delivered as a subject: Natural Sciences.

The science curriculum includes four educational fields: Physics, Chemistry, Natural Sciences and Geography. The biology thematic areas covered in the FEP are presented in Tab. 8.

Tab. 8: The basic structure of biology instruction divided into Learning areas and thematic fields in the FEP (the Czech Republic) (VƯP, 2007)

\begin{tabular}{llll}
\hline Grade & $\begin{array}{l}1-3 \\
(\text { age } 6-9)\end{array}$ & $\begin{array}{l}3-5 \\
(\text { age } 9-11)\end{array}$ & $\begin{array}{l}6-9 \\
\text { (age 11-15) }\end{array}$ \\
\hline Learning areas & Man and His World & Man and His World & Man and Nature \\
\hline Thematic areas & Diversity of Nature & Diversity of Nature & $\begin{array}{l}\text { General Biology and } \\
\text { Genetics }\end{array}$ \\
& & & $\begin{array}{l}\text { Fungal Biology } \\
\text { Plant Biology }\end{array}$ \\
& & Animal Biology \\
\hline & & $\begin{array}{l}\text { Human Biology } \\
\text { Inanimate Nature }\end{array}$ \\
& & $\begin{array}{l}\text { Essentials of Ecology } \\
\text { Empirical Exploration } \\
\text { of Nature }\end{array}$ \\
\hline
\end{tabular}

The learning objectives are recorded by means of learning outcomes. The learning outcomes define general requirements on science instruction and learning content that each pupil should be taught. Science content is recorded by means of operational verbs.

Tab. 9: The learning outcomes defined for the topic of "food chains" across educational stages covering primary and lower secondary education in the Czech Republic (VÚP, 2007)

\begin{tabular}{|c|c|c|}
\hline $\begin{array}{l}\text { Grade 1-3 } \\
\text { (age 6-9) }\end{array}$ & $\begin{array}{l}\text { Grade } 3-5 \\
\text { (age 9-11) }\end{array}$ & $\begin{array}{l}\text { Grade } 6-9 \\
\text { (age 11-15) }\end{array}$ \\
\hline$\overline{-}$ & $\begin{array}{l}\text { The pupil: } \\
\text { Study basic communities in } \\
\text { selected localities of regions, } \\
\text { explain principal mutual } \\
\text { relations between organisms, } \\
\text { and identify shared and } \\
\text { different features in the } \\
\text { adaptation of organisms to the } \\
\text { environment }\end{array}$ & $\begin{array}{l}\text { The pupil: } \\
\text { Give examples of the } \\
\text { occurrence of organisms in } \\
\text { a specific environment and the } \\
\text { relations between them. } \\
\text { Explain the nature of simple } \\
\text { food chains in various } \\
\text { ecosystems and evaluate their } \\
\text { importance. }\end{array}$ \\
\hline
\end{tabular}


Tab. 10: Learning objectives for developing particular biology knowledge (the topic of cell and its structure) and procedural knowledge by 11-14 years pupils (the Czech Republic) (VÚP, 2007)

\begin{tabular}{|c|c|}
\hline $\begin{array}{l}\text { Disciplinary content - } \\
\text { Biology }\end{array}$ & The pupil: \\
\hline $\begin{array}{l}\text { General Biology and } \\
\text { Genetics }\end{array}$ & $\begin{array}{l}\text { - } \text { recognises the basic manifestations of life and its } \\
\text { conditions and becomes familiar with the outline of the } \\
\text { evolution of organisms } \\
\text { - describes the basic differences between plant, animal and } \\
\text { bacterial cells and explains the functions of basic } \\
\text { organelles } \\
\text { - recognises, compares and explains the functions of basic } \\
\text { plant and animal organs (organ systems) } \\
\text { - classifies organisms and places selected organisms into } \\
\text { kingdoms and lower taxonomic units } \\
\text { - explains the basic principles of sexual and asexual } \\
\text { reproduction and their importance in terms of heredity } \\
\text { as exames examples of heredity from everyday life, as well } \\
\text { of organisms environmental influence on the formation } \\
\text { - explains the significance of viruses and bacteria in nature } \\
\text { and for Man on examples from everyday life }\end{array}$ \\
\hline $\begin{array}{l}\text { Empirical exploration of } \\
\text { nature }\end{array}$ & $\begin{array}{l}\text { - applies empirical methods of exploring nature } \\
\text { - observes the basic safety rules of work and conduct when } \\
\text { becoming acquainted with animate and inanimate nature }\end{array}$ \\
\hline
\end{tabular}

\section{FINDINGS}

Question 1: Regarding the two theory perspectives (new institutionalism and policy borrowing) it is interesting analyse either different national curricula developed in similar contexts or similar national curricula developed in different contexts. During designing curriculum in the Czech Republic, inspiration was sought in foreign curriculum documents, specifically in Scotland, England, Norway, Denmark, Sweden, Hungary, etc. (Tupý, 2014). It is obvious that Scottish CfE and Czech FEP stem from similar ideology and mechanisms for reforming curriculum in schools. Both curricula aim to move away from the centrally prescribed, disciplinary-isolated, and knowledge overloaded curriculum to a model based on constructivist pedagogy, relying on the professionalism of teachers and "soft" key competencies/capacities as a crucial goal of education (Holec \& Dvořák, 2017).

Most importantly, the quality of implementation was very different in the compared countries. While the Scottish curriculum is accepted by many teachers the Czech reform is perceived as unsuccessful in school implementation and the readiness of many teachers for the transition from the centrally prescribed, disciplinaryoriented curriculum to curriculum emphasizing key competencies and relying on teachers as agents of curriculum change (Dvořák, Holec \& Dvořáková, 2018). These problems are often explained by the low support provided to schools and teachers during the implementation phase of the reform and/or by the attitudes of conservative teachers (Straková, 2013; Dvořák \& Holec, v recenzním řízení). 
The impact of globalization the science curriculum and its impact on the curriculum is an interesting topic for research but it depends on acquiring comparable data on school curricula from sufficient numbers of countries (Stacey et al. 2018). The globalisation of local educational policies can be partly explained by transnational influence particularly results of TIMSS and PISA studies (Dvořák \& Holec, v recenzním řízení). The result of the TIMSS and PISA studies are being a key factor affecting the educational policies significantly as the countries attempt to improve their performance in international point of view Both Scottish and Czech educational policies reacted to decreasing results in PISA by more detailed description of learning outcomes and their standardization. In England, there is a rising interest in defining core knowledge and skills to be delivered in particular academic disciplines (Young, 2007). It is highly important the current National Curriculum in England took place approximately 10 years after the curriculum reforms in Scotland and the Czech Republic. National Curriculum represents a different model to curriculum making focused on developing key knowledge and skills in learning content without defining key skill apart from the disciplines. A further study of the National Curriculum may bring an impulse for innovating the Czech curriculum in reflecting both knowledge and competencies in the revised learning content.

Question 2: As expected, there were significant differences among the analysed curricula, both in organisational approach and thematic areas. First of all, the biology content differs significantly by the way of how biology topics are organised in each curriculum.

CfE defines broad thematic areas of biology instruction - biodiversity and interdependence; body systems and cells; inheritance. These concepts are developed across all levels of Scottish compulsory education. In contrast, NC defines specific thematic areas emphasizing an academic approach to learning science. The thematic areas differ in each level of compulsory education in England. During the early years, there are broad topics relevant mostly to a systematic approach to content organisation in curricula (e.g. animals, including humans; plants, rocks). In lower secondary education, biology topics focus on developing academic disciplinary knowledge. The biology education leads to developing concepts of photosynthesis; cellular respiration; nutrition and digestion etc. Similarly to CfE, Czech FEP prescribes a broad thematic area "diversity of nature" at primary education. In contrast, during lower secondary education, the Czech curriculum employs thematic categories that reflect the systematic approach to classifying organisms (e.g. plant biology, fungal biology, animal biology, human biology). This content organisation is similar to the NC approach in terms of developing academic knowledge.

I compared expected learning outcomes focusing on the topics of food chains and cell and its organisation. In the analysis, I focused on how the statements of outcomes and objectives differ in their cognitive demands. Moreover, I wanted to find out whether these outcomes represent academic disciplinary knowledge or practical everyday knowledge.

Firstly, I analysed the learning objectives intended for primary education. The following examples show the learning outcomes for the topic "food chains". According to Bloom's revisited taxonomy (Bloom \& Krathwohl, 2001), the outcomes are intended to develop both understanding the content knowledge and its application:

Pupils should be taught to: construct and interpret a variety of food chains, identifying producers, predators and prey. (NC, Key stage 2 Science) 
Learning in the sciences will enable me to: I can use my knowledge of the interactions and energy flow between plants and animals in ecosystems, food chains and webs. I have contributed to the design or conservation of a wildlife area. (CfE, second level Science)

The pupil: studies basic communities in selected localities of regions, explains principal mutual relations between organisms, and identifies shared and different features in the adaptation of organisms to the environment. (FEP, Grade 3-5, Man and his world - Diversity of nature)

Secondly, the analysis was focused on statements of objectives referring to lower secondary education. The outcomes cited below focus on developing content knowledge in the topic of cell and its organisation. According to Bloom's taxonomy of cognitive education goals, the outcomes cited below tended to signal emphasis on the most advanced cognitive skills and metacognitive knowledge in the case of $\mathrm{NC}$ and CfE. In contrast, the FEP statement of learning objectives focuses on prescriptive knowledge and basic cognitive skills including remembering and understanding content knowledge.

Pupils should be taught about: cells as the fundamental unit of living organisms, including how to observe, interpret and record cell structure using a light microscope. (NC, Key stage 3 Science)

Learning in the sciences will enable me to: by researching cell division, I can explain its role in growth and repair and can discuss how some cells can be used therapeutically. (CfE, third and fourth level Science)

The pupil: describes the basic differences between plant, animal and bacterial cells and explains the functions of basic organelles. (FEP, Grade 6-9, Man and Nature - Natural Sciences)

I can, therefore, conclude here that, at the level of curricular statements of outcomes, the intention is that disciplinary knowledge is gifted a high degree of importance, both in terms of content knowledge and procedural knowledge. It is obvious from the examples of cited learning outcomes that the idea of key competencies is imprinted in all analysed curricula. In the CfE and FEP, key competencies are stated as the main principles underpinning the education in Scotland and the Czech Republic. On the other hand, English NC emphasis disciplinary key knowledge and skills as an integrated part of its learning outcomes. It does not separate key competencies from the learning content.

Focusing on statements of curricular intent at least, there is a discrepancy between primary and lower secondary education in the Czech curriculum. The statements of outcomes for lower secondary education are highly descriptive focusing on basic cognitive skills, whereas the primary education outcomes emphasize procedural knowledge leading to expected disciplinary outcomes.

\section{CONCLUSIONS}

The analyses suggest that, in some respects, there are global trends shaping curriculum reforms in the compared countries. The quality of implementation differs significantly in dependence on the capacity of the entire education system to do so. Scotland is a typical lending country of policy origin while the Czech Republic as 
a country of policy borrowing. English National Curriculum represents an educational policy emphasizing traditional academic disciplines embedded in disciplinary knowledge. Further research may bring an understanding of how this curriculum model can impact global educational policy.

The comparative analyses showed that at least judging from three curriculum documents included in the analysis, pupils develop both disciplinary knowledge and procedural knowledge during their science/biology study. Disciplinary knowledge continues to be a key purpose within the analysed curricula and statements of intended outcomes as disciplinary objectives are arguably one of the most important purposes. All compared curricula differ significantly in the disciplinary content organisation, statement of intended outcomes of learning and the coherence of particular topics.

In compared countries, biology learning content in educational policy intentions is organised into thematic areas at different levels of organisation. Scottish Curriculum for Excellence classifies the science content on significant concepts of learning with a special emphasis on curriculum coherence. For this purpose, the thematic areas remain the same across all educational levels. In Curriculum for Excellence, the disciplinary knowledge uses basic cognitive aims at first and later employs more advanced types of knowledge. There is an explicit intention that disciplinary content should not be heavily prescribed, but should be flexible to decisions made by the teachers.

In spite of similarities between Czech and Scottish curricula from the point of view of the curriculum reform and competence-oriented curriculum, there are distinctive differences in learning statements organisation and their content between Curriculum for Excellence and Czech Framework Educational Programme. In the Framework Educational Programme, the biology learning content is structured into traditional systematic domains related to biological taxonomy in lower secondary education. The statements of intended learning outcomes are strongly prescriptive in content-based mainly on the own educational objectives rather than the process of learning and knowledge as an instrument to achieve the objectives. Contrary, the learning objectives in Framework Educational Programme primary education prioritise the process of learning and disciplinary knowledge as an instrument to achieve competence-based outcomes. I argue for the distinctive inconsistency in the biology learning objectives between primary and lower secondary curriculum. While the primary education outcomes for Science (Diversity of Nature) are dominantly focused on making science, the lower secondary outcomes for Biology (Natural Science) are based predominantly on delivering descriptive knowledge. Judging from the learning objectives, pupils are learned to recall and understand biology facts and phenomena rather than to use their knowledge in purpose to solve scientific and biology problems.

Focusing on the English National Curriculum, the biology disciplinary content relates both to the traditional systematic approach (noticeably during Key Stage 1 and Key Stage 2) and later predominantly on key biology concepts. The disciplinary objectives ensure that children are taught the essential knowledge in particular subject disciplines. National Curriculum represents a traditional subject-oriented curriculum centred on academic achievements. Compared to the Czech Framework Educational Programme, the outcomes are more specific, both in content knowledge and procedural knowledge and skills. 


\section{REFERENCES}

Anderson, L. W. \& Krathwohl, D. R., et al. (2001). A taxonomy for learning, teaching and assessing: A revision of Bloom's taxonomy of educational objectives. New York: Longman.

Blažek, R. \& Př́hodová, S. (2016). Mezinárodni šetření PISA 2015: Národní zpráva: Přírodovědná gramotnost. Ceská školní inspekce.

Bowen, G. A. (2009). Document analysis as a qualitative research method. Qualitative Research Journal, 9(2), 27-40. https://doi.org/10.3316/QRJ0902027

Bruner, J.S. (1960). The process of education. Boston: Harvard University Press.

Council of the European Union. (2018). Council recommendation on key competences for lifelong learning. Brussels: Council of the European Union.

Department for Education. (2013). The National Curriculum in England: Key stages 1 and 2 framework document. London: Department for Education.

Department for Education. (2014). The National Curriculum in England: Key stages 3 and 4 framework document. London: Department for Education.

Department for Education. (2013). Reform of the National Curriculum in England: Government response to the consultation, conducted February-April 2013. London: DfE.

Drucker, P. F. (2004). Managing in the next society. European Business Review, 16(4), 426-427. https://doi.org/10.1108/09555340410547044

Dvořák, D. \& Holec, J. (Submitted.) Similar principles, similar weaknesses?

A comparison of the Czech and Scottish curricular reforms. The Curriculum Journal.

Dvořák, D., Holec, J. \& Dvořáková, D. (2018). Kurikulum školního vzdělávání:

Zahraniční reformy $v$ 21. století. Praha: PedF UK.

European Council. (2000). Presidency conclusions, Lisbon European Council 23 and 24 March 2000. Brussels: European Council.

Goodlad, J. I. \& Su, Z. (1992). Organization of the curriculum. In P. W. Jackson (Ed.), Handbook of Research on Curriculum, (327-344). New York: Macmillan.

Holec, J. \& Dvořák, D. (2017). Curriculum for Excellence: Kurikulum založené na kompetencích a zkušenosti z jeho implementace. Pedagogika, 67(1), 56-77.

https://doi.org/10.14712/23362189.2017.429

Hutchinson, C. \& Hayward, L. (2005). The journey so far: Assessment for learning in Scotland. Curriculum Journal, 16(2), 225-248.

https://doi.org/10.1080/09585170500136184

Meyer, J.W. (2010). World society, institutional theories, and the actor. Annual Review of Sociology, 36(1), 1-20. https://doi.org/10.1146/annurev.soc.012809.102506

Meyer, H. D. \& Rowan, B. (Eds.). (2006). The new institutionalism in education. Albany: State University of New York Press.

Mullis, I. V. \& Martin, M. O. (2014). TIMMS advanced 2015 assessment frameworks. International association for the evaluation of educational achievement. Amsterdam, Netherlands.

Oates, T. (2011). Could do better: Using international comparisons to refine the

National Curriculum in England. Curriculum Journal, 22(2), 121-150.

https://doi.org/10.1080/09585176.2011.578908 
OECD. (2016). PISA 2015 assessment and analytical framework: Science, reading, mathematic and financial literacy. OECD publishing.

Osborne, J. \& Dillon, J. (2008). Science education in Europe: A report to the Nuffield foundation. London: King's College. Retrieved March, 17(2010), 261-278.

Priestley, M. (2010). Curriculum for Excellence: Transformational change or business as usual. Scottish Educational Review, 42(1), 23-36.

Priestley, M. \& Humes, W. (2010). The development of Scotland's curriculum for Excellence: Amnesia and déjà vu. Oxford Review of Education, 36(3), 345-361. https://doi.org/10.1080/03054980903518951

Priestley, M. \& Minty, S. (2012). Developing curriculum for Excellence: Summary of findings from research undertaken in a Scottish local authority. University of Stirling. Available from https://dspace.stir.ac.uk/bitstream/1893/7075/1/

Stirling\%20CfE\%20research\%20-\%20report_March\%202012.pdf

Pritchett, L., Woolcock, M. \& Andrews, M. (2010). Capability traps? The mechanisms of persistent implementation failure. CGD Working Paper 234. Washington, D.C: Center for Global Development.

Ramirez, F. O. \& Meyer, J. W. (2002). National curricula: World models and national historical legacies. Stanford University.

Schmidt, W.H., McKnight, C. C., Houang, R. T., Wang, H., Wiley, D. E., Cogan, L.S. \& Wolfe, R. G. (2001). Why schools matter: A cross-national comparison of curriculum and learning. San Francisco: The Jossey-Bass Education Series.

Schmidt, W.H. \& Prawat, R.S. (2006). Curriculum coherence and national control of education: Issue or non-issue? Journal of Curriculum Studies, 38(6), 641-658.

https://doi.org/10.1080/00220270600682804

Scottish Executive. (2004). A curriculum for excellence. Edinburgh.

Scottish Executive. (2006a). A Curriculum for Excellence: Building the curriculum 1: The contribution of curriculum areas. Edinburgh.

Scottish Executive. (2006b). A Curriculum for Excellence: Progress and proposals. Edinburgh.

Scottish Executive. (2007). A curriculum for excellence: Building the curriculum 2: Active learning in the early years. Edinburgh.

Scottish Executive. (2008). Building the curriculum 3: A framework for learning and teaching. Edinburgh.

Stacey, O., De Lazzari, G., Grayson, H., Griffin, H., Jones, E., Taylor, A. \& Thomas, D. (2018). The globalization of science curricula. Springer International Publishing.

Steiner-Khamsi, G. (2014). Cross-national policy borrowing: Understanding reception and translation. Asia Pacific Journal of Education, 34(2), 153-167.

https://doi.org/10.1080/02188791.2013.875649

Straková, J. (2013). Jak dál s kurikulární reformou. Pedagogická orientace, 23(5), 734-743. https://doi.org/10.5817/PedOr2013-5-734

Škoda, J. \& Doulík, P. (2009). Vývoj paradigmat přírodovědného vzdělávání. Pedagogická orientace, 19(3), 24-44.

Tupý, J. (2014). Tvorba kurikulárních dokumentů v České republice:

Historicko-analytický pohled na př́pravu kurikulárních dokumentũ pro základní vzdělávání v letech 1989-2013. Brno: Masarykova univerzita. 
Van den Akker, J. (2004). Curriculum perspectives: An introduction. In Curriculum landscapes and trends (1-10). Dordrecht: Springer.

VÚP. (2007). Framework educational programme for elementary education (PEP EE). Prague.

Walterová, E. (1994). Kurikulum - proměny a trendy v mezinárodni perspektivě. Brno: Masarykova univerzita.

Wiseman, A. W., Astiz, M. F. \& Baker, D. P. (2014). Comparative education research framed by neoinstitutional theory: A review of diverse approaches and conflicting assumptions. Compare, 44(5), 688-709. https://doi.org/10.1080/03057925.2013.800783

Young, M. (2007). Bringing knowledge back in: From social constructivism to social realism in the sociology of education. Routledge.

JAKUB HOLEC, holec.jakub@gmail.com

National Institute for Education

Weilova 1271/6, 10200 Prague 10, Czech Republic 